\title{
A Needs Analysis for the Course Materials Design of the Arabic Language Course
}

\author{
Ashinida Aladdin
}

\begin{abstract}
The Arabic course the Faculty of Law at The National University of Malaysia is offered to all first year students in second semester as a compulsory course. Students taking this course are made up of students who have different religious backgrounds and ethnicity namely Malay, Chinese, Indian, Sikh, Iban, Kadazan, to name but a few. To Malay ethnic students who are Muslims, Arabic is the language that is familiar to them as compared to students from other ethnicities and religious backgrounds who have never studied Arabic before. It is undeniable that the students face challenges and difficulties during the teaching and learning process. One of the challenges they find is the course materials, which is difficult for them. One of the demotivational factors in learning Arabic language is course materials. Currently, the students use instructional materials provided by the teachers. These teaching materials are a textbook and supplement texts selected from various relevant and reliable sources. Hence, the aim of this paper is to highlight the initial findings of the needs analysis on the course materials to provide insight in order to better design and develop the teaching materials for the Arabic course.
\end{abstract}

Index Terms-Arabic language, course materials design, Malaysia, needs analysis.

\section{INTRODUCTION}

Malaysia is known for its diverse population in South East Asia. As a multi-ethnic, multi-cultural and multi-religious country, Malaysia can be a platform for learning various foreign languages in order to promote better understanding with regard to different peoples and different cultures, especially in terms of understanding the Muslim culture in Malaysia itself. However, in the Malaysian context, Arabic language is always perceived to be taught only to the Malay ethnic population who are Muslim by religion.

In the National University of Malaysia known as Universiti Kebangsaan Malaysia (henceforth UKM), all undergraduate students from different faculties are required to take foreign language course as elective subject offered by the Unit of Foreign Languages and Translation at School of Language Studies and Linguistics. By exposing the students to other foreign languages i.e. Arabic, French German, Japanese, Korean, Spanish, Thai and others, they are equipped with foreign language competency in order to face the challenges in the real world especially to compete and survive in the workplace [1]. In the Faculty of Law, Arabic language is

Manuscript received January 3, 2015; revised March 8, 2015.

Ashinida Aladdin is with the School of Language Studies and Linguistics, Faculty of Social Sciences and Humanities, The National University of Malaysia (Universiti Kebagsaan Malaysia), Malaysia (e-mail: ashi@ukm.edu.my). compulsory to all undergraduate students.

The Faculty of Law (henceforth FoL) in UKM was established on the 1st February, 1984 and its mission is to become an entity which is successful in producing legal professionals of excellent knowledge, ethics, appearance and personality within the framework of the national culture. It also aims to produce well trained and skilled graduates in various fields of law and practice, including the Sharic ${ }^{c}$ ah Law. The degree offered by the Law Faculty is Bachelor of Law with Honours. The minimum period of study is eight semesters and the maximum is twelve semesters. The uniqueness of the Faculty of Law in UKM is that, it is the only faculty at UKM that offered Arabic language as a compulsory subject to all its students regardless of their ethnicities and religion.

Arabic language plays an important role for students of Law in UKM. Learning Arabic language assists the students in understanding terminologies found in Islamic Law known as Shari 'ah Law subjects which form part of the syllabus for undergraduate law students. Islamic law subjects form almost $30 \%$ of the total subjects undertaken by undergraduate law student in Law Faculty UKM. Islamic Law subjects include Introduction to Islamic Legal System, Islamic Criminal Law, Islamic Family Law, Transaction in Islamic Law, Islamic Banking and Finance, Islamic Jurisprudence, Shari 'ah Court Evidence and Procedure. Many Arabic terms are used in these subjects. Therefore, learning the Arabic language provides an exposure to the students on the context and usage of the language in Islamic law.

The second reason why teaching Arabic language is important to Law students in UKM, is because Islamic Law is part of the Malaysian legal system. Consequently, any law student has to have a certain level of knowledge and understanding of Islamic law for Muslims in Malaysia. Many of the primary sources and major references for Islamic law are written in the Arabic language. Thus, it is important for the students to know the Arabic language in order to enable them to make references to the Arabic legal text at later stage.

Malaysia is trying to maintain its position as a leading nation in Islamic banking and finance. To fulfil the domestic needs of consumers, most banks have established Islamic counters to offer Islamic banking products and services either to Muslims or non-Muslims. For that reason, as future legal practitioners, Law students of UKM must have a certain level of knowledge relating to Islamic banking and finance which is rooted in Arabic language.

Furthermore, Malaysia is aiming to position itself as the world halal hub. To comply with JAKIM (Department of Islamic Development Malaysia), as the owner of the halal trademark, all companies dealing with food have to employ 
legal officers who are well-versed in Shari 'ah principle and Islamic Law in Malaysia. This is the opportunity for students of Law from UKM to fill in the vacancies. Having additional knowledge in the Arabic language, especially for the non-Muslims, would give them a better advantage as compared to those who did not learn the Arabic language. They would be able to understand the Islamic law terminologies (usually in Arabic) and comprehend the discussion conducted by Islamic religious officers pertaining to the principles of permissibility for Muslims.

Besides Malay language as a national language and English as a second language in Malaysia, learning a foreign language is an advantage and produces versatile students who are able to communicate in several different languages. For students of Law in UKM, mastering the Arabic language will give them a better edge in the legal world where they can understand Arabic terms that are widely used in Islamic jurisprudence, Islamic banking and finance, as well as the halal industry.

In the Faculty of Law, the students are required to take three levels of Arabic language namely Preparatory Arabic (SKVA2552) in the first semester of Year One. This course is specially designed for the non-Muslims who have no background at all in Arabic language. After undertaking this course the students will move to the Arabic 1 for the Faculty of Law (SKVA2562) in the second semester of Year One; and finally the Arabic 2 for the Faculty of Law (SKVA2572) in the first semester of Year Two. The rationale for learning Arabic is because they will need to study Islamic Law subjects i.e. Islamic Legal System, Islamic Criminal Law, Islamic Family Law, Islamic Judiciary Law, Islamic Transactions, Evidence and Procedure in Shari'ah Court and Law of Islamic Banking and Takaful and knowledge of Arabic is therefore essential.

In order to get the degree, the students must pass all Arabic language examinations. However, the student is allowed to re-sit the examination if they fail. In addition to that, the third and fourth year students in the Faculty of Law are also entitled to take a Diploma Programme in Judiciary and Islamic Advocacy offered by the Faculty of Islamic Studies, UKM in which one of the admission requirements is to have a basic knowledge in the Arabic language. The objective of this programme is to provide opportunities to the graduates of Shari ${ }^{c} a h$ and Judiciary to conduct an in-depth study in Judiciary and Islamic Advocacy administration [2].

The contact hours for the course are 4 hours per week for 14 weeks which make 56 contact hours per semester. The assessment is based on the objective of particular course that includes language learning skills i.e., listening, speaking, reading and writing. In Arabic I for Faculty of Law, it offers exercises in writing and reading in modern standard Arabic texts. The students will be trained to read and write through Arabic short texts and basic grammatical aspects will also be stressed. At the end of the course, the students will be able to read and understand modern standard Arabic texts as well as Arabic grammar. Some Islamic legislative terms are also introduced. The students are currently using the textbook called Hayya bi al-'arabiyyah, supplement texts from other sources as well as using relevant websites and CDs for teaching and learning [3].

Course materials form an important part in teaching Arabic language. As mentioned, the diverse forms course materials are used to support teaching and learning process of the language. However, despite the importance of the course materials, it is one of the demotivational factors in learning Arabic as a foreign language among the non-Muslims Malaysian learners of Arabic [4]. Based on the findings, it is crucial to re-evaluate the existing course materials for SKVA2562 in order to design and develop an innovative course design. In designing a language course it is vital to carry out a needs analysis to determine the specific reasons for learning the language [5]. In addition to the learners' objective needs, learners' subjective needs, that is, their affective needs, such as their interests, wishes, expectations and preferences should take into consideration when designing the course [6]. To conclude, the goal of needs analysis is to collect information that can be used to develop a profile of the language needs of a group of learners in order to be able to make decisions about the goals and content of a language course [7]. Furthermore, needs analysis should not only be considered as a pre-stage for the design of language courses; in fact, it is an "on-going process" [8] and, as evaluation, it can be used to design, improve and implement language programmes.

Therefore, the aim of this project is to design and develop an innovative course material for SKVA 2562 Arab 1 for the Faculty of Law. This paper will report on the preliminary findings on the needs analysis in the first instance in which will be used to determine the key components necessary for designing a course material. A course outline will then be designed to accommodate these needs.

\section{METHODS}

\section{A. Instrument}

This research employs a qualitative approach. The qualitative data obtained by means of the open-ended questionnaire were distributed to the respondents. At the initial stage, all the responses or comments in the open-ended questions were listed. After analysing the written responses thoroughly, the codification were made carefully, and then followed by the process of data analysis. The data and the results were then presented in tabular form to show the calculations of frequencies and percentages.

\section{B. Participants}

The respondents were 100 students who are undertaking SKVA2572 Arabic language II at current semester i.e. Semester 1 Year 2 which means that they have just finished their course in SKVA2562 Arabic language I in Semester 2 Year 1 who are able to give necessary feedbacks, comments and criticism on the course materials that have been used in the previous Arabic course i.e. SKVA2562 Arabic language I.

\section{RESULT}

In this research, Jolly \& Bolitho's seven step-model in course design [9] was adopted and it began with the first step, i.e. identifying the targeted learners' needs. The data gathered by mean of open-ended questionnaire to acquire learners' 
needs in the Arabic course material as presented in the table below.

TABLE I: RESULT ON TARGETED LEARNERS' NEEDS OF ANALYSIS ON COURSE MATERIALS

\begin{tabular}{|c|c|c|}
\hline Responses & $\begin{array}{l}\text { Frequecy } \\
\quad(f)\end{array}$ & Percentage \\
\hline $\begin{array}{l}\text { a. Need to have romanized or } \\
\text { transliterated version. }\end{array}$ & 91 & 14.4 \\
\hline $\begin{array}{l}\text { b. Need colourful pages instead of } \\
\text { black and white. }\end{array}$ & 87 & 13.8 \\
\hline $\begin{array}{l}\text { c. Need to focused not only the } \\
\text { grammars, but more } \\
\text { vocabularies and interesting } \\
\text { reading texts. }\end{array}$ & 83 & 13.2 \\
\hline $\begin{array}{l}\text { d. Need of vowelization/diacritics } \\
\text { in every word. }\end{array}$ & 82 & 12.9 \\
\hline $\begin{array}{l}\text { e. Need of glossary of } \\
\text { vocabularies at the end of } \\
\text { each chapter/unit. }\end{array}$ & 81 & 12.8 \\
\hline $\begin{array}{l}\text { f. Need of CDs for listening, } \\
\text { pronunciation and reading } \\
\text { exercises. }\end{array}$ & 78 & 12.4 \\
\hline g. Need bigger font size. & 68 & 10.8 \\
\hline $\begin{array}{l}\text { h. Need of clearer instructions in } \\
\text { the text book/course material }\end{array}$ & 61 & 9.7 \\
\hline Total & 631 & 100 \\
\hline
\end{tabular}

Table I reveals the results of targeted learners' needs analysis on course materials. There are eight main themes were coded. The need of the romanized and transliterated version of the textbook ranked the first with $f=91,14.4 \%$, followed by the need on colourful pages with $f=87,13.8 \%$ and the textbook needs to focus not only on grammars but also on vocabularies and interesting reading text with $f=83,13.2 \%$. The need on the vowelization or diacritics in every words in textbook is considered important to the learners with $f=82$, $12.9 \%$. Following that is the need to have glossary at the end of each chapter with $f=81,12.8 \%$, followed by the need of $\mathrm{CD}$ for listening, pronunciation and reading exercises with $f=$ $78,12.4 \%$, followed by bigger font size with $f=68,10.8 \%$ and the need of clearer instructions in the textbook with $f=61$, $9.7 \%$.

\section{DISCUSSION}

The learners of Arabic in the Faculty of Law found that there is a crucial need on the course materials or textbook be romanized or the transliteration version in in order to enable the students to read the textbooks on their own. In fact, the purpose for not having the transliteration in the existing textbook is to familiarize the students with reading in Arabic alphabets rather that becoming dependent on the Roman alphabets. Even though the aim is to familiarize the students, it seems that the students are not benefitting from such an approach. The students are too dependent on their teachers in the classroom instead. With this finding, it is recommended that to design the Arabic course material, it is vital to reconsider the issue and provide transliteration for the beginner students (level 1) in order to assist them to be less dependent on their teachers and become autonomous learners.

The respondents also expressed their concern on the focus of course materials which needs to be vary and not only focus on grammar, but in vocabularies as well as interesting reading texts. In this case, Arabic teachers and course designers need to be professionally prepared with skills to write, evaluate, and know what and how to create, select, adapt and enrich the course materials to sustain students' interest in learning the language [10]. It is also significant to provide the vocalisation system or diacritics in every word in the textbook for beginners. In Arabic language, a word is a combination of consonants and short vowels. In order for the Arabic beginners learners, to be able to read a word, or a phrase or a sentence, the learners have to master the alphabet in both forms i.e. standalone form and in its joining form; and at the same time need to identify and practically use the diacritics which consist of vowels to help them in reading any word, phrase or sentence.

From the findings also, in terms of pronunciation accuracy of Arabic words, it is suggested that for the beginner level, the Arabic words, phrases and sentences must be fully vowelized in the textbook or teaching materials in order to assist the learners to comprehend the Arabic pronunciation as well as their reading skills which will also lead them to master the Arabic orthography. A study confirms that the diacritics that mark the short vowels in fully vowelized orthography often clarify the correct pronunciation of the written word [11]. This is in line with [12] and [13] findings where poorly skilled and skilled participants, showed significant reading improvement in the fully vowelized condition across all the stimulus materials among all participants. Thus, vowels served as good facilitators for both skilled and poor readers.

The respondents also suggested that the layout of the textbook be made more attractive with colourful pages, bigger font size, with glossary after each unit or chapter as well as producing a $\mathrm{CD}$ will be taken into consideration in designing and developing an innovative course material for SKVA 2562 as a next stage of the project.

\section{CONCLUSION}

In this paper, it reports on the preliminary findings of the needs analysis on Arabic language course materials. From the data, it is obvious that the textbook/course materials are one of the important factors that influence the learners' motivation in learning. If the learning materials are improperly prepared, it may affect negatively the learners' motivation to continue to learn Arabic. Thus, teachers, syllabus and course designers have to put efforts to design and develop attractive and innovative course materials. It should focus on an interesting and stimulating materials and contents together with an attractive layout and design to cultivate motivation among the learners of Arabic language.

\section{ACKNOWLEDGMENT}

The authors would like to express their gratitude to the Universiti Kebangsaan Malaysia for funding this research (Project code: GGPM-2012-058). 


\section{REFERENCES}

[1] Z. Ahmad and I. H. Abdullah, "Undergraduate language education at Universiti Kebangsaan Malaysia: Current and future prospects," in Proc. the 4th Comparative Education Society of Asia Biennial Conference, Universitas Pendidikan Indonesia, Bandung, 20-22, July 2003.

[2] Buku Panduan Siswazah, Fakulti Pengajian Islam, Sesi 2011-2012, (Postgraduate Student's Handbook, Faculty of Islamic Studies, Session 2011-2012), Universiti Kebangsaan Malaysia, Bangi, pp. 121-124, 2011.

[3] Buku Panduan Prasiswazah, Fakulti Sains Sosial dan Kemanusiaan, Sesi Akademik 2011-2012, (Student's Handbook for Undergraduate, Faculty of Social Sciences and Humanities, Session 2011-2012), Universiti Kebangsaan Malaysia, Bangi, pp. 113-114, 2011.

[4] A. Aladdin, "Demotivating factors in the Arabic language clasroom: What demotivates non-Muslim Malaysian learners when it comes to learning Arabic?" in Procedia - Social and Behavioral Sciences, vol. 93, pp. 1652-1657, 2013.

[5] T. Hutchinson and A. Waters, "Needs analysis," in English for Specific Purposes, T. Hutchinson and A. Waters, Eds. Cambridge: Cambridge University Press, pp. 53-64, 1987.

[6] D. Nunan, The Learner-Centred Curriculum, Cambridge: Cambridge University Press, 1988.

[7] J. Clark, Curriculum Renewal in School Foreign Language Learning, Oxford: Oxford University Press, 1989.

[8] R. White, The ELT Curriculum, Cambridge: Basil Blackwel, p. 91. 1998.

[9] D. Jolly and R. Bolitho, "Framework for materials writing," in Materials Development in Language Teaching, B. Tomlinson, Ed., Cambridge: Cambridge University Press, pp. 90-115, 1998.

[10] L. England, "Methodology in Arabic language teacher education," in Handbookfor Arabic Language Teaching Professional, K. M. Wahba, Z. A. Taha, and L. England, Eds. Mahwah, New Jersey: Lawrence Erlbaum, pp. 409-418, 2006.
[11] R. Azzam, "The nature of Arabic reading and spelling errors of young children: A descriptive study," Reading and Writing: An Interdisciplinary Journal, vol. 5, pp. 355-385, 1993.

[12] S. A. Rabia, "The role of vowels and context in reading of highly skilled native Arab readers," Journal of Psycholinguistic Research, vol. 25, pp. 629-641, 1996.

[13] S. A. Rabia, "Multicultural and problematic social contexts and their contribution to L2 learning," Language, Culture and Curriculum, vol. 8, no. 2, pp. 183-199, 1997.

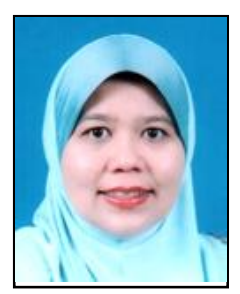

Ashinida Aladdin is a senior lecturer in the University of Malaysia (UKM) in Arabic language as a second/foreign language and was an Arabic course co-odinator for seven years. She is in charged in teaching Arabic as a second/foreign language to the undergraduate students as well as responsible in developing the Arabic language modules for beginners and intermediate level. The courses thatc teachs are Arabic beginner, intermediate and advance. She also supervising $\mathrm{PhD}$ students from Malaysia, Jordan, Yemen and Sudan. she obatained she PhD in 2012 from University of Aberdeen, Scotland, United Kingdom in the field of Arabic language studies.

She research areas are in psychological aspects in second/foreign language learning. She research related to attitudes, motivational orientations and demotivation in learning Arabic as a foreign language in multicultural Malaysia. Other research interests are comparison between aspects of linguistics in Arabic and Malay language, communication strategies, Computer Assisted Language Learning (CALL) and vocabulary building in FL learning.

She have actively engaged presenting papers in conferences locally and internationally and have published book and articles in refereed journals. 